\title{
LANGUANGE FUNCTION FOUND IN MULAN MOVIE
}

\author{
Ni Kadek Dian Wahyuni ${ }^{1}$, Ni Nyoman Deni Ariyaningsih ${ }^{2}$ and I \\ Made Iwan Indrawan Jendra ${ }^{3}$ \\ Mahasaraswati Denpasar University, Indonesia ${ }^{123}$ \\ dianw2506@gmail.com nym.deni@yahoo.com \\ iwanindrawan300573@gmail.com
}

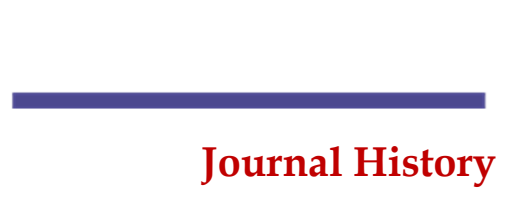

Submitted 27th January 2021

Revised 12th March 2021

Accepted 21 ${ }^{\text {st }}$ April 2021

Published 29th July 2021

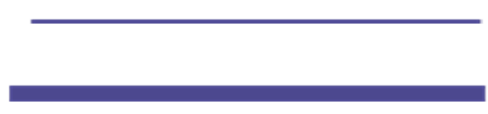

Keywords:

Language Function, Characters Expression, Mulan Movie

\begin{abstract}
This study concerned with the language function found in Mulan movie. The data source was taken from conversation among the characters in Mulan movie. The data was collected by using observation method based on library research. There were some steps in collecting the data. The qualitative method was the method that was used in analysing the data in this study. The conversation among the characters analysed in the category types of language function that was according to the book written by Blundell (1987) entitled Function in English. The data was presented by the formal method which presented the language function. The research finding showed that there are four type of Language Function: main function, social formula, making communication work and finding out about language. Based on the data, there are 33 data for main function, 15 data for social formulas and 2 data for making communication work. The study concluded that the most used language function was main function and the least used language function was finding out about language.
\end{abstract}

\section{INTRODUCTION}

Sociolinguistics defines as a study of society aspects and language that is used by human in their daily life. Wardaugh $(1998$, p. 12) states that sociolinguistics is concern with investigating the relationships between language and society with the goal being a better understanding of the structure of language and how languages function in communication, while Gumperz in Wardaugh $(1998$, p. 11) states that sociolinguistics is an attempt 
to find correlations between social structure and linguistic structure and to observe any changes that occurs." They are interested in explaining why we speak differently in different social contexts, and they are concerned with identifying the social function of language and the ways it is used to convey social meaning. According to Martinez (2015) Language is nothing but human subjects in as much as they speak, say and know. Words are used to describe and inform, as well as to involve and persuade the hearers (Lestari, 2019). The use of language has been helping the human being's life such as to transfer information, feelings, or ideas from one to another person both in spoken and written form. Language also can connect the people who are from different countries and with different mother tongues. The existence of global language is very important to connect the people around the world. English as the global language have been used to have communication in society and to connect the people in the world.

According to Crystal (2003) English is global language that is used by people around the world. People use English to express their feeling, emotions, utterance to other people. Movie makers take English as one of languages that is normally used in their movie. English movie will have a big market, because English is used in world wide. In this entertainment industry, learning language function is necessary for the characters in the movie. Language function is helpful in analysing the utterance of all characters.

Language function will be used in the conversation of the characters. The characters should be able to use the language function according the situation. Language function is one of the important things that the characters should know and understand well when the characters have conversations each other in the movie. The sentences which are spoken by the characters, for example: to ask for information, offer to do something to someone or say sorry. The right use of language function can explain the utterance of what the characters want to do.

The study of language function can make the audiences are able to understand the felling, emotions and expression in Mulan movie. It can be helpful to promote the understanding of language expressions (Lestari, et al., 2017). One of the examples of language function, asking for information in Mulan movie is 'Is this your family sword?' and introducing yourself in Mulan movie is 'I am Hua Zhou'. Mulan movie is a 2020 American actiondrama movie produced by Walt Disney Pictures. This movie has an interesting story that is easy to be understood.

\section{METHODS}

The data sources were taken from the conversation among the characters in Mulan movie. The release date of this movie for the streaming version was on 4th September 2020 and was produced by Walt Disney 
Pictures. The data in this study collected by using observation method and based on library research. By using qualitative method, the data in this study analysed in the category types of language function that was according to the book written by Blundell (1987) entitled Function in English. The data were presented in formal and informal method.

\section{RESULTS AND DISCUSSION}

\section{RESULT}

The data were divided into four language function which were main function, social formulas, communication work, and finding out about language.

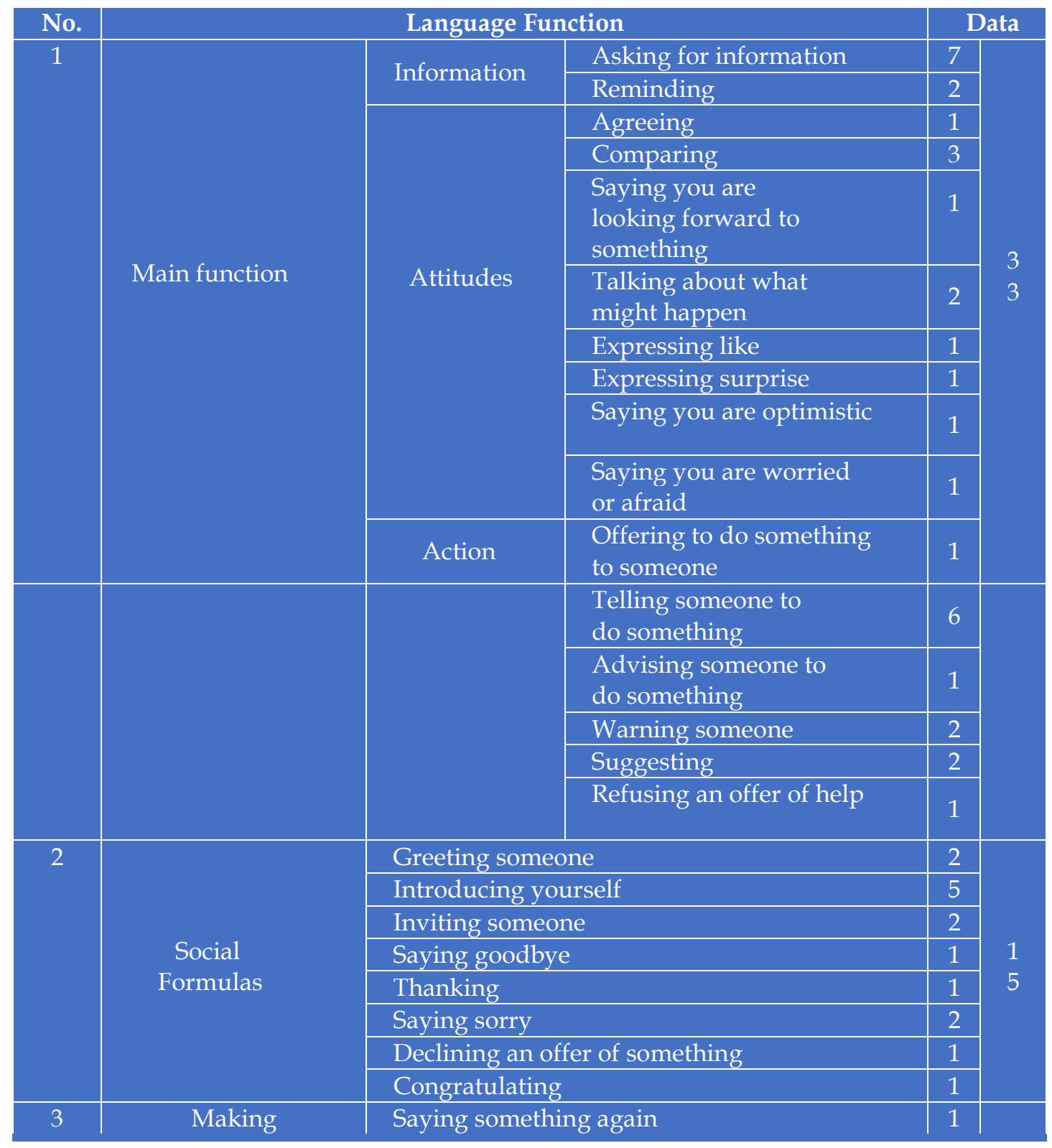




\begin{tabular}{|c|c|c|c|}
\hline $\begin{array}{l}\text { Communicatio } \mathrm{n} \\
\text { work }\end{array}$ & Giving example & 1 & 2 \\
\hline & Total & $\begin{array}{l}5 \\
0\end{array}$ & $\begin{array}{l}5 \\
0\end{array}$ \\
\hline
\end{tabular}

\subsection{Main Funtion, social formulas}

There are three types of function in this section: informational, attitudinal, and action (Blundell, 1987: 5)

\subsubsection{Attitudinal}

00.37.15-00.37.17

Cricket : I like kissing women with cherry red lips

Yao : I don't care what she looks like

Mulan: I agree

Yao : I care what she looks like

According to data above, there was a language function of Agreeing which was 'I agree'. From the statement uttered by Yao, he did not care with what did his liked woman or typical women looked like. Hearing the statement of Yao, Mulan agreed with what Yao had already said. It was an agreeing language function that used to accept the same idea with another people. However, Yao was made a joke to his friends. Among their friendship, they liked to make jokes and showed that their relationship was really close.

\subsubsection{Action}

Honghui : Need a hand little man?

Mulan : Insult me again and you'll taste the tip of my blade.

Commander :Lower your sword. Mulan:Or what?

Based on the conversation above, there was a language function of Refusing an offer of help which was 'Insult me again and you'll taste the tip of my blade'. That statement was uttered Mulan who under covered herself into a man named Hua Jun. Mulan refused an offer of help from Honghui, because she fell down to the ground. Honghui wanted tohelp Mulan. However, Mulan ignored the offer of help from Honghui. And she said 'Insult me again and you'll taste the tip of my blade'. Mulan intimidated to attack Honghui, if he insulted her again.

\subsubsection{Informational}

00:10:05 - 00:10:16

Emperor :Who is responsible?

Chancellor :Rourans Your Majesty. Their leader calls himself Böri Khan.

The utterance above is kind of language function which belongs to Asking for information which was 'Who is responsible?'. The Emperor were 
asking for information to the Chancellor about who was the mastermind of the attack that was happened in the Imperial City. The chancellor answered that the mastermind of the attack was Rouans which was leaded by Bori Khan.

\subsection{Social Formulas}

Sergeant : :Have you seen Hua Jun? Hua Jun? Mulan

:I am Hua

\section{Mulan. Forgive me.}

Cricket :He is a girl?

According to the data above, it refers to a language function of saying sorry which was 'Forgive me'. From the conversation above, the Sergeant was searching for Hua Jun or Mulan. And suddenly, there were a woman was walking closer to the Commander and she was Hua Jun. Hua Jun or Mulan wanted to uncover her real identity to her friend and the Commander. She released that what she had done was a big mistake. Therefore, she was saying sorry to the Commander, because she had cheated on him.

Commander :What is your name?

Mulan:Hua Jun Commander.

According to data above there was a language function of Introducing yourself which was 'Hua Jun Commander'. Based on the conversation between Commander Tung and Mulan, the Commander was asking for the name of Mulan or Hua Jun. The Commander wanted to know more about Hua Jun or Mulan, because Hua Jun or Mulan could be able use Chi power which was not many people able to use it. Hua Jun or Mulan responded the question of the Commander and introduced herself as Hua Jun.

\subsection{Making Communication Work}

Yao :A courageous woman?

Mulan:Yes. And she has a sense of humour. She's also smart.

The conversation above is kind of a language function of Giving an example which was 'Yes. And she has a sense of humour. She's also smart'. From the conversation between Hua Jun or Mulan and Yao above, Yao asked Hua Jun about how was the courageous woman he meant. Mulan who under covered herself into a man named Hua Jun gave Yao the example of typical woman that he liked. The example of typical woman of Hua Jun was a woman with a sense of humour and she is also smart woman 


\section{CONCLUSION}

This study analysed types of Language Function Found in Mulan Movie. In line with the objective of the research, to find out the types of language function in Mulan movie used the book written by Blundell (1987). The writer selected Mulan movie become a data source in this study and in order to analyse the types of language function. There were fifty conversation are found in Mulan movie and categorized as main function, social formulas, and making communication work. There is no data found in finding out about language.

From analysing the conversation of Mulan movie, main function is the most used in the conversation of Mulan movie there are 33 conversation. Next, social formulas; there are 15 conversation, making communication work consist of 2 conversation and the least is finding out about language; there is no data found.

\section{REFERENCES}

Aliyah, Istinganatun. 2015. "Language Functions of Toyota Advertisements Headlines". Thesis. English Department, Faculty of Arab and Cultural Sciences: State Islamic University Sunan Kalijaga Yogyakarta.

Ashari, Lilik. 2019. "Language Function Found in the Conversation between Guest Relation Officer and Guest in Risata Bali Resort and Spa Hotel". Thesis. English Study Program of STIBA Saraswati Denpasar.

Blundell, Jon. 1987. "Function in English". Oxford University Press.

Cristal, David. 2003. "English is a Global Language". Cambridge: Cambridge University Press.

Lestari, D., Suastra, IM., Pastika, IW., Sedeng, IN. 2017. Developing A Method of Learning English Speaking Skills Based on the Language Functions Used in the Food and Beverage Service. E-Journal of Linguistics.

https://ocs.unud.ac.id/index.php/eol/article/download/26468/1 $\underline{7884}$

Lestari, D. (2019). Persuasive Function in Food and Beverage Service: A Sociolinguistics Approach. Advances in Social Science, Education and Humanities Research, 353, 22-28. https://doi.org/10.2991/icosihess19.2019.4 
Martinez, Jesus. 2015. "International Journal of Language and Linguistics". Journal. Department of Philology, Faculty of Business Studies and Tourism: Universidad de Almeria, Almeria, Spain.

Novita Dewix, Ni Kadek. 2016. "English Expressions Spoken by the Administrative Staff of PT. Sinar Media Kreasi". E-Journal. English Department, Faculty of Letters and Culture, Udayana University.

Trailer, Movie. 2019. “Mulan Official Trailer Disney Movie” Retrieved from Youtube : https:/ / www.youtube.com/watch?v=arf96ael 